September -2009

\title{
An Evaluative Study of a Distance Teacher Education Program in a University in Ghana
}

\author{
Kwasi Addo Sampong \\ Central University College, Ghana
}

\begin{abstract}
The study used an adaptation of Provus' discrepancy evaluation model to evaluate a distance teacher education program in the University of Cape Coast, the premier teacher education institution in Ghana. The study involved comparing performance data of the program as perceived by students and faculty/administrators to standards prepared from the program's design. Performance data was obtained by administering two survey instruments to a random sample of students and faculty/administrators. Discrepancies between performance and standards were reported. The study concluded that although there were some discrepancies between program standards and performance the program is fulfilling its purpose of upgrading the professional and academic performance of a large number of teachers in the public K-8 schools in Ghana.
\end{abstract}

\section{Distance Teacher Education at the University of Cape Coast, Ghana}

Distance education (DE) as a complementary mode of delivery was initiated as an effort to overcome the challenges of access, equity, cost-effectiveness, and quality for higher education (Association for the Development of Education in Africa [ADEA], 2002; Perraton, 2000). The suitability of DE for teacher preparation in particular is a topic of interest in many countries (Perraton, Creed, \& Robinson, 2002; Shachar \& Neumann, 2003).

Ghana, like other industrialized and developing countries, relies on DE to augment traditional face-to-face methods of teacher education (Perraton, Robinson, \& Creed, 2007). Teacher preparation is well established in the country with 40 Colleges of Education that offer three-year postsecondary certificate "A" diplomas for teachers of basic education. Total annual matriculation of teachers from these institutions has been between 5,500 and 6,000 since 1995 (Akyeampong, Furlong, \& Lewin, 2000). However, there is an acute shortage of trained teachers, created by an expansion of pre-tertiary enrollments due to rapid population growth, the success of basic education reform, and the inability of Colleges of Education to produce the required number of teachers because of inadequate infrastructure. This shortage is not limited to Ghana but is prevalent in all countries of sub-Saharan Africa (DeJaeghere, Chapman, \& Mulkeen, 2004, 2006). 
A study done in 2000 reported that to train all untrained teachers in Ghana by the year 2005 and to achieve a gross enrollment ratio of a hundred percent by the year 2010, the total number of new teachers required per annum would be from 13,000 to 16,000 , and this output would have to be sustained up to the year 2010. Considering the current total annual output of trained teachers, meeting the demand for new teachers is a daunting task (Akyeampong et al., 2000; Akyeampong, 2001).

To overcome the shortage of trained teachers, education policy makers decided to employ the mass-production potential of distance education, identified by Peters (1971) nearly 40 years ago. $\mathrm{DE}$ is therefore used for in-service training of active but untrained teachers and for professional upgrading of already trained teachers in K-8 schools (Perraton, 1993; 2000; Perraton et al., 2002; Robinson \& Latchem, 2002; Saint, 1999).

With the introduction of DE, the Ministry of Education (2002) intended to solve not only the shortage of teachers but also the high attrition rates often associated with study leave. In addition, the Ministry of Education wanted to ensure that teachers would not need to move from their duty stations to seek further education. They could remain at post and learn by integrating college work with their teaching work (Darling-Hammond, 1998). DE has the potential to stem high attrition rates of teachers and reduce the migration of teachers from K-8 classrooms to high school or college classrooms after they have received higher qualifications and have gained additional experience.

The Center for Continuing Education of the University of Cape Coast (CCEUCC) introduced a three-year diploma in Basic Education (DBE) program in 2001 and by 2006 had 8,336 students at 18 study centers in all 10 administrative regions. It initiated post-diploma (P-DBE) programs in the 2005-2006 academic year (Brown, 2004; Ministry of Education, 2002, 2004; Ossei-Anto, 2003).

\section{Distance Education and Evaluation}

Successful program development cannot occur without evaluation (Sanders, 2000). The value of evaluation, especially pertaining to DE, has been variously discussed. Calder (1994) and Thorpe (1988) have suggested several important reasons for evaluation in DE. Evaluation helps distance educators to gather information about learners and their needs and desires. It is needed because DE is still in its embryonic innovative stage and pioneering activities are still taking place within the industry. It assists distance educators in thinking about what they are trying to do and what they hope to achieve as they implement programs and activities. Evaluation can also provide information needed by external bodies, funding agencies, businesses, colleges, students, and other clients who want to know if DE accomplishes what it sets out to do. The literature on evaluation of DE mostly deals with comparison studies of one mode over the other, mostly correspondence over traditional, face-to-face DE, or of one medium over the other.

Program evaluation is the systematic investigation of the worth of an ongoing or continuing activity. There are as many different models of or approaches to evaluation as there are 
philosophical underpinnings of definitions of evaluation. The needs of each particular program determine the evaluation model suitable for use (Simonson, 1997). The literature suggests that professional evaluators usually prefer an eclectic use of parts of various models, as Madaus and Kellaghan (2000) state:

Each evaluation approach has its particular strengths that can help illuminate different aspects of a program. Within the limitations of the budget, pick and choose features from various models that can provide the best evidence to answer questions about the project. For example, consider combining test data from a goals-oriented approach, resource allocation data from the decision-oriented approach, and observational and interview data from the naturalistic approach. (p. 25)

\section{The Nature of the Problem}

Teacher preparation by the DE mode of delivery was introduced in Ghana almost a decade ago to accelerate the production of trained teachers and to enhance the quality of teaching in K-8 schools. No standard has been articulated to measure the success of the program. Evaluation is crucial to the development of any program (Mark, Henry, \& Julnes, 2000), yet despite the key role that evaluation plays in program development, no systematic formative program evaluation has so far been conducted in the country (Ministry of Education, 2002; R. Aggor, personal communication, May 15, 2005).

The purpose of this study was to evaluate the distance teacher education program at the University of Cape Coast, Ghana's premier teacher preparation institution.

\section{The Research Question}

The research question was, "how well is a large distance education program fulfilling its purposes for teacher education in Ghana?" Specifically, are there discrepancies between the standards for the design of the distance teacher education program in Ghana and the actual performance in the field?

\section{Theoretical Perspective and Research Model}

The research question was answered using an objectives-oriented, quantitative evaluation study, based on an adaptation of Provus' discrepancy evaluation model (DEM) (Provus, 1971). Provus developed this model for use as new programs were designed and implemented in the Pittsburgh public schools. He used a systems approach to determine whether program performance met accepted program standards. Provus conceptualized a three-step process of program evaluation: (a) defining program standards, (b) determining whether a discrepancy exists between some 
aspect of the program performance and the standards governing that aspect of the program, and (c) using discrepancy information either to change performance or to modify program standards.

In Provus' original model, the evaluator is involved in the design of the program as well as the standards for assessment, in consultation with stakeholders. With the design and standards in hand, she evaluates each of the five stages of the program, namely design, installation, process, product, and cost, by comparing the standards with the performance. The comparison often shows differences between standard and performance (i.e., expected and actual); this difference is called discrepancy. Discrepancy information is provided to the program staff, giving them a rational basis on which to make adjustments in their program (Provus, 1971).

The DEM has been used in a variety of educational contexts. Householder and Boser (1991) included it in an assessment of the effectiveness of change in teacher technology education. Morgan (1999) used it to evaluate an educational technology program design and implementation in a community college in California. The Center for Evaluation and Research also used it to evaluate Oakland Unified School District's Urban Dreams Technology Challenge Grant Project (CER, 2001).

This study uses an adaptation of the DEM to evaluate an existing program at the University of Cape Coast, the largest such program in Ghana.

In preparation for stage one of the evaluation, the plan of the program was obtained from the University of Cape Coast. Following Steinmetz (2000), a component analysis of the design was performed. The program was broken down into five major activities or components using Rumble's (2002) categorizations, namely student-teacher achievement, course material production, tutoring, classroom supervision, and administration. This provided a conceptual model, or a program map, which showed how the program looked and facilitated component analysis. It included (a) the inputs for the whole program (resources provided by the Ministry of Education, the University of Cape Coast, and the Commonwealth of Learning); (b) the process for the whole program (the development and implementation of distance teacher education); and (c) the output (i.e., to provide higher academic and professional training for basic school teachers, raise performance level of teachers, and equip teachers with skills for lifetime learning). It also includes the five components mentioned above (see Figure 1). 


\section{CENTRE FOR CONTINUING EDUCATION UNIVERSITY OF CAPE COAST}

TEACHER DISTANCE EDUCATION (DBE \& P-DBE)

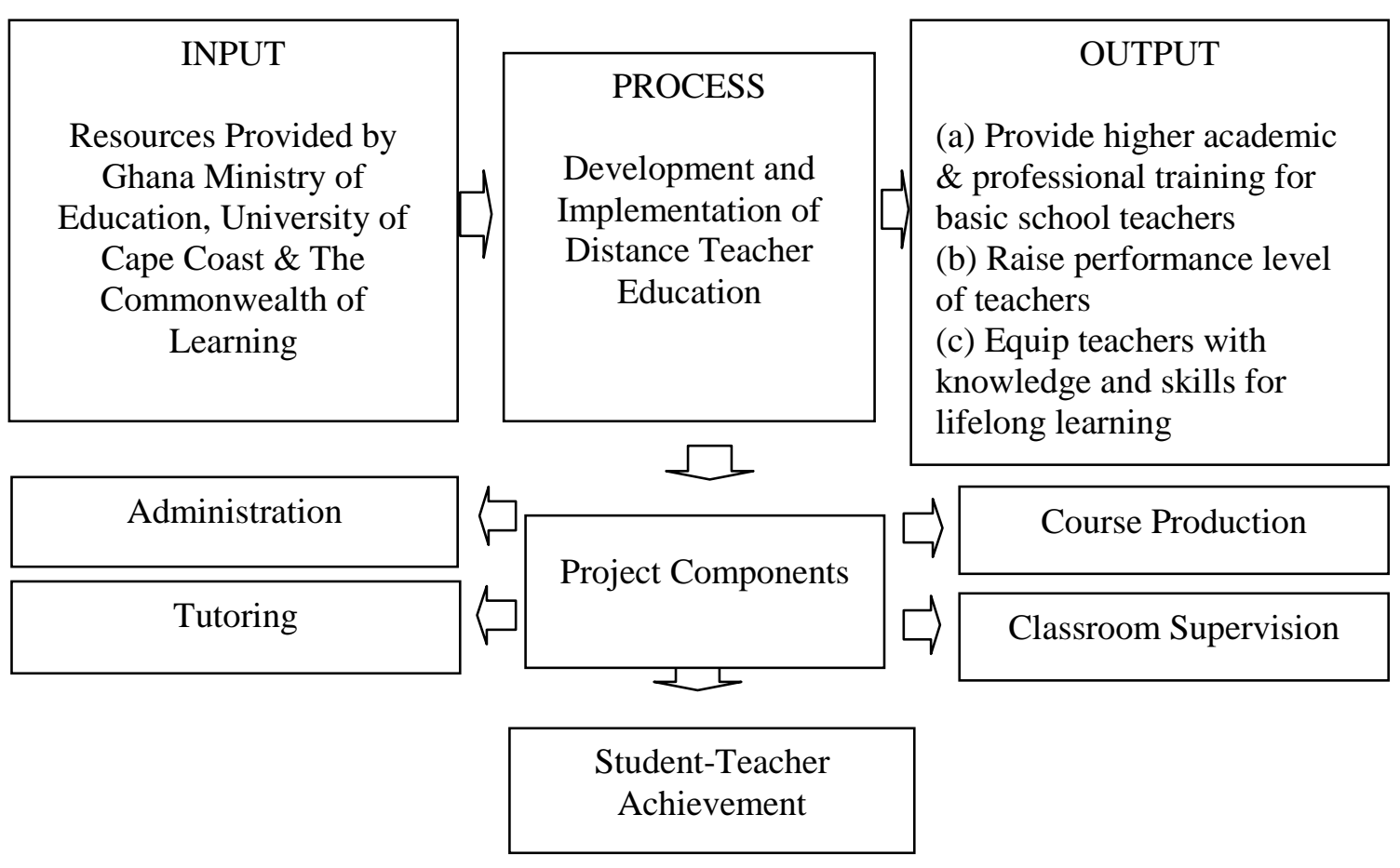

Figure 1. Program map of the plan of CCEUCC, showing the input, process, and output, as well as the project components.

From this program map a component analysis was derived. It consisted of input-process-output (IPO) narratives for each component, along with what Steinmetz calls a "program network," showing all components and subcomponents and the major relationships among them (see Figure 2). With this design in hand, an official of CCUECC was interviewed concerning the view of the administration on what the ideal program should look like. The standards for the program were written specifying the intent or expectations of the program. The standards were based on the answers received from this interview, the objectives of the program, and the ADEA Report (2004), which contains critical success factors for DE in Africa. 




Figure 2. Program network showing the various components and the interconnections between them.

\section{Program Narrative}

The University of Cape Coast was established in 1962 and mandated to train graduate professional teachers for the country's high schools and to assist with training of teachers for the K-8 schools through its graduates, who teach in the Colleges of Education of Ghana. The university was instrumental in the design and implementation of the Education Reforms of 1987. Challenges that emerged with the implementation of the education reforms included the need to 
increase the number of qualified teachers in the basic schools to keep up with a recent expansion in enrollment in basic education and the need to improve academic and pedagogical competencies of the bulk of teachers in the basic schools. The Centre for Continuing Education was established to mount two programs to train teachers through distance education. By providing a viable distance learning program, the Centre seeks to achieve the following:

- provide higher academic and professional training for teachers in the basic school,

- increase access to university education,

- raise the performance level of teachers in the basic schools and personnel of the Ghana Education Service, and

- equip students with knowledge and skills for lifelong learning. (CCEUCC, n. d.)

\section{Methods and Procedure}

The study sought to examine the perceptions of the teacher trainees as well as faculty/administrators to ascertain gaps, if any, between standards and performance of the distance teacher education program of the University of Cape Coast. This was done by administering two sets of questionnaires to two groups of people: students and faculty/administrators.

\section{The Setting and Sampling}

The research site, the University of Cape Coast in Ghana, has over 8,000 distant teacher trainees in its program, scattered across the country. They are involved in two programs: a three-year diploma in Basic Education (DBE), and a higher, two-year post-diploma degree in Basic Education (P-DBE). Student teachers from both programs were included in the study because the two programs together constitute the University's work in distance teacher education. Out of this total population, second and third year DBE students and all P-DBE students were used for this study, making a select population of 6,897. Responses from the student teachers from the two programs were not differentiated because the two programs are very similar and differ only in terms of the specific content of their courses, with the P-DBE following the DBE.

A random sample of 365 students and 186 (out of 350) administrators and faculty members were obtained. Two sets of survey questionnaires were developed and pretested by the researcher and were administered to the students and faculty/administrators with the help of coordinators at the various study centers. Usable returned questionnaires yielded a response rate of $41 \%$ of students and $42 \%$ of faculty/administrators.

\section{Analysis of the Data}

Returned questionnaires were manually entered into a spreadsheet and analyzed at two levels. First, descriptive statistics were calculated in the frequency count and percentage of responses for 
each item. These gave the number of respondents and the frequency of respondents who marked Strongly Agree, Agree, No Opinion, Disagree, and Strongly Disagree.

A second level of analysis of the data was done by collapsing the categories of responses to present the composite counts and frequencies of those who had either agreed or disagreed.

\section{Stage One Evaluation}

The first stage of the evaluation included deriving the design of the program from the documents provided by the university. The standards of the program were derived from the program design, from interviewing an official of the university, and from a review of the literature. Finally, the curriculum was assessed by two people, one with a Ph.D. in Education and the other with an Ed.D., both of whom have done extensive work in the area of curriculum. This phase of evaluation was crucial for it enabled the researcher to formulate the statements on the survey questionnaires to elicit the perceptions of the student body as well as the faculty/administrator group. It was determined that it was possible for CCEUCC to implement a viable program and that expert reviews found the curriculum appropriate for teacher education.

\section{Stage Two Evaluation}

The second stage of the evaluation measured installation of the program. An analysis of responses indicated that some issues needed to be dealt with in order to close the gap between the design and the installation of the program. The students' and faculty/administrators' positive responses were $63.74 \%$ and $58.18 \%$ respectively, and their average percentage was 62.59 . This represented a relatively high rating of the installation of the program by both groups. However the low positive scores from respondents regarding two major issues, raised in the open-ended comments, indicated some discrepancy.

The first issue that needed to be addressed was the lack of computers with Internet connectivity at the study centers, which were meant to enhance research and easy communication among students and between students and course tutors. This was a concern for both students and faculty/administrator groups given that this item received the lowest positive response from both groups.

The second issue was the frequency and effectiveness of classroom supervision; this item received less than $50 \%$ positive response from student respondents. Two students suggested in the open-ended section that classroom supervision "needs improvement." However they failed to indicate the kind of improvement in supervision that was needed (which could be either the frequency of supervision, or the quality of supervision, or both). Nevertheless the students' response was confirmed by the faculty/administrator group who also gave a low rating $(28.1 \%$ agreement) to a similar item on whether supervisors' reports are analyzed and used to improve the program. Three faculty/administrators suggested that there was the need for provision of vehicles at the various learning centers to enhance effective supervision, especially of studentteachers stationed in remote and inaccessible rural areas. This suggests that supervisors might be 
facing logistical problems and are therefore unable to perform their supervisory duties satisfactorily.

One more issue of concern to both student and faculty/administrator groups was the financial burden of the payment of tuition and the purchase of study manuals by the student teachers. This concern came from 18 student respondents and from two faculty/administrators on the openended section. It is the opinion of the researcher that this complaint stems from the fact that the government has traditionally provided scholarships and stipends for student teachers in the various Colleges of Education. Therefore student teachers involved in the program do not understand why the same benefit is not extended to them. The frustration of the student teachers about this was summed up by a statement from one of the respondents: "As a teacher in the classroom, I feel I should get support from the government."

Two students and one faculty/administrator expressed a desire for the distance learning program to be separated from the main university administration. Their reason was to enhance efficient management, indicating a lack of satisfaction with the way the program was managed. Faculty/administrators did not rate positively the item about whether learner information is collected, stored, and used on a consistent basis, again showing concern about a lack of efficient management of information storage and retrieval systems.

Also there was one comment each from a student and a faculty/administrator on the need to create more learning centers. Two faculty/administrators suggested that course tutors must be involved in course writing; and one faculty/administrator suggested that there should be more coordination between administrators and tutors.

\section{Discussion of stage two evaluation.}

Tait $(2000$; 2003) suggested that student support services perform cognitive, affective, and systemic functions. The cognitive learner support function develops learning through the course materials and resources for students; the affective student support function provides an environment that helps students, creates commitment to learning, and enhances students' selfesteem; and the systemic learner support function establishes administrative procedures and information management systems characterized by efficiency, transparency, and studentfriendliness. Tait's systemic learner support function seems to be lacking in the implementation of the program. Respondents agreed that information gathering and an information storage system were needed. They agreed that supervisors and tutors did not collect information from students for transmission to headquarters to be stored and retrieved for further planning. According to an ADEA Report (2004), effective distance education requires the collection, maintenance, and use of learner information. The report further states that "management of information is needed monitoring information will enable providers to identify and act to support inactive or at-risk learners" (p.13).

Furthermore, there seemed to be no supervision of the supervisors, who were charged with observation of the student-teachers in their classrooms to ensure that they were practicing what 
they were taught. On paper, supervisors were expected to visit students and to observe their teaching on a biweekly basis then write a report. However both student and faculty/administrator respondents agreed that this was not being done effectively. Faculty/administrators suggested that provision of vehicles at the study centers would enhance the work of supervisors, especially those who have to travel to distant rural areas where student teachers are stationed.

\section{Stage Three Evaluation}

The third stage of the evaluation measured the extent to which interim products compared with the standards. The interim products were identified as the course manuals, the materials distribution processes, the course delivery systems, and the student support systems. An analysis of the responses in this section of the questionnaire indicated that the students' positive response was $73.22 \%$. Among faculty/administrators' $69.26 \%$ responded positively. The average positive response rate for both groups was $72.40 \%$.

Two statements received positive responses lower than $50 \%$ in this section. The first is the item that indicated that the students would have liked to have had more contact with their course tutors, which received $82.9 \%$ agreement from students. This implied that only $17.10 \%$ were satisfied with the contact they had with their tutors. The second statement inquired whether the tutors returned graded assignments to them in a reasonable time, which yielded $45.5 \%$ agreement.

The percentages of faculty/administrators' positive responses were lowest on two statements: there is a time block earmarked for one-on-one interaction between instructors and students who need it, and course writers actually visit study centers and try to get feedback from students and course tutors on how their manuals are used. The former statement corresponds to the item on the student questionnaire that asked about students' satisfaction with the contact with their course tutors, which showed only $17 \%$ agreement.

Responses in the open-ended commentary section indicated that students felt that the courses were overloaded, and they had difficulty balancing their roles as adults, teachers, and students, a concern shared by one faculty/administrator. They also complained about the quizzes and examinations, saying that they were not given adequate time to complete them, and their complaints were not dealt with satisfactorily. This was also supported by faculty/administrators, who suggested more emphasis on staff development to enhance student support.

Another critical comment from both student and faculty/administrator groups was that course manuals were not properly edited, revised, and distributed, and that sometimes students did not receive their materials at the beginning of the semester.

In spite of these problems, the 71.24 percentage of positive responses in the questionnaires indicates a relatively small gap between perception of performance and standard. Thus both student and faculty/administrator groups rate the performance of the program highly. 


\section{Discussion of stage three evaluation.}

Tait's $(2000 ; 2003)$ affective learner support function seems to be lacking in this program. A majority of student respondents agreed that they needed more contact with tutors (faculty), and tutors agreed they did not have a time block allocated to one-on-one contact with students during the biweekly face-to-face seminars at the study centers. This indicates that learners' need for more contact with course tutors seems to have been neglected in designing the program. In a situation where contact with tutors by way of email and telephone is difficult due to the inadequacy of information and communications technology facilities in the country (Butcher, 2003; Saint, 1999) and especially in rural contexts, this is a serious drawback. According to Tait, learner support should be personalized in such a way that learners' needs are responded to immediately.

Zhao et al. (2005) observe that as a distance education program increases the opportunity for more interaction, it increases the chance of being better rated than its face-to-face counterpart. They again observe that distance education becomes more effective when there is a "live" instructor present, i.e., either occasional face-to-face contact or contact through an information technology medium.

Thorpe (2003) suggested that learners need support in two areas: institutional systems and course materials. Institutional systems support includes publishing which courses are available, how to apply, how to make payments, etc., before, during, and after the course of study. Course materials support includes answering learners' questions on how to make sense of something in the course materials, how to complete a particular assignment, how to contact other students, and other related services. The program of the Center for Continuing Education of the University of Cape Coast needs to be strengthened in both areas of learner support. The second area of support emphasizes personal contact with tutors. Although provision has been made in the program for biweekly face-to-face seminars, there has been no provision for one-on-one student-tutor advising.

Open-ended responses indicated that there is no identified process of development and evaluation of course manuals. The implication is that only a few course writers were contracted to write the course manuals, and there was no mechanism for feedback from the course tutors and students who used them. Feedback about course materials from students, tutors, and study center coordinators must become a part of the materials revision process. This would help to make the course materials learner-centered, clear to the students, and self-explanatory. Furthermore, it is crucial to ensure efficient distribution of materials to students at the beginning of the semester in order to avoid wasting time.

Students need to be encouraged to be independent learners. The more independent students' learning becomes, the more competent they will feel and operate. This would decrease their need for access to their tutors (Grow, 1991; Wlodkowski, 1999). Faculty responses indicated that approximately $70 \%$ encouraged their students to consider comments on their graded assignments as dialogue and $30 \%$ did not. This compares to student responses to a similar question about 
whether they regarded comments on their graded assignments as dialogue, to which $75 \%$ responded in the affirmative and $25 \%$ responded in the negative. Brindley (1995) suggested the end goal of learner support to be the enhancement of independent learners and empowerment of students, which is all the more pertinent in this program since students are adult learners and practicing teachers. They need to be guided to move through the three intermediate stages identified by Grow (1991) as dependent, interested, and involved towards the ultimate goal of self-directed learning. This is the only way they can move from Schon's (1987) knowing-inaction to reflection-in-action. It is important to develop effective, reflective teacher practitioners (Darling-Hammond, 1998) and to achieve the program's objective of equipping student teachers with the skills of lifelong learning.

\section{Stage Four Evaluation}

The fourth stage of the evaluation measured terminal products, the academic and professional competence of students. An analysis of student responses indicated that $78.05 \%$ of students' responses were positive. Almost all students (94.3\%) agreed that the program contributed to their academic and professional development. The next highest percentage of positive responses was to the statement about whether they would recommend CCEUCC correspondence courses to their friends, relatives, etc. who are in the teaching profession, to which $80.5 \%$ responded positively. The statement that they prefer DE to classroom instruction yielded a rather low positive response of $41.5 \%$. Positive responses by faculty showed that $93.8 \%$ agreed with the statement that the distance teacher education program has had a positive impact on teacher education in Ghana, and 90.6\% agreed that the students were utilizing what they learned in the program in their classrooms.

The percentage of positive responses for the stage four evaluation was $78.05 \%$ for students and $92.2 \%$ for faculty/administrators, with an average percentage of $80.97 \%$, which shows that both groups gave the highest rating to the stage four evaluation..

The comments of both student and faculty/administrator groups were very complimentary to the program. Both groups agreed that the program was helping to upgrade the professional and academic competence of the student teachers.

\section{Discussion of stage four evaluation.}

Students agreed that the distance education program contributed to their academic and professional development, and they would recommend the program to their friends and relations, yet, at the same time, they indicated their preference for a face-to-face program. This seems contradictory, but it is consistent with the literature. Alexander et al. (2003) reported that it took online students more time than students in traditional classrooms to complete course objectives. Allen et al. (2002) conducted a meta-analysis using 23 studies and concluded that while the difference in levels of academic achievement between students involved in both 
traditional and distance education is insignificant, both groups tended to prefer traditional education over DE.

Teaching has been considered to be a matter of skill rather than a matter of acquiring information. According to Shulman (2004), teaching requires basic communication skills, content knowledge, and pedagogical skills. Yet both the students and the faculty confirm that a DE program has enhanced the professional capability of teachers. Perraton et al. (2002) affirm that teacher preparation mostly comprises a balance between four elements: improving general educational background, increasing knowledge and understanding of the content area, enhancing pedagogy and the understanding of children and their learning, and developing practical skills and competencies. Perraton et al. suggested that the underlying purpose of a particular teacher education program determines the proportion and mix of these elements, and where the emphasis has been to raise teachers' background education or where the program is designed to help experienced teachers learn about a new subject, classroom activities have not been given much emphasis.

In the case of practical skills acquisition in a distance teacher education program, the component of practicum has been considered to be very important. Perraton et al. (2002) have itemized different examples of distance teacher education programs, which show different levels of practicum compositions: (1) no practicum at all; (2) college-based micro teaching; (3) classroombased practicum as a separate block in a course, usually placed after academic blocks; (4) classroom-based practicum supervised by staff from college; and (5) classroom-based practicum under the guidance of a mentor within the school.

CCEUCC has contracted supervisors (trained teacher educators in regional and district offices of the Ghana Education Service) and tutors of training colleges to visit the student teachers' classrooms biweekly to observe the student teachers in action and to send reports to the Center. Teacher preparation at a distance has a potential advantage over traditional education because it is possible to integrate theory and practice by enabling practicing teachers to stay on the job while raising their skills. This might be the reason for the high rating of the program by the student teachers and faculty. The students who participated in this study are already involved in teaching, and therefore it is easier to transfer the concepts they are learning to the classroom. The positive responses for the participants in this study indicate that pre-service teacher education at a distance may also work as effectively if the practicum component is designed properly and is well supervised by experienced master-teachers.

Admittedly, the success of the program under review should be measured by principals, senior teachers, or outside evaluators, who would compare the teachers' effectiveness in the classroom with a control group, being their counterparts who did not benefit from the distance education. However, time and other constraints prevented this. 


\section{Conclusion}

The distance teacher education program of the Center for Continuing Education of the University of Cape Coast (CCEUCC) is fulfilling its purpose of upgrading the academic and professional competence of a large number of teachers in the basic schools in Ghana, raising their performance level and equipping them with skills for lifelong learning. The gap between these objectives and the program's performance, as perceived by students in the program, faculty, and administrators, is not so big that it cannot be closed. Constant review of performance is needed to completely close the gap. Further, this program would be enhanced if students and tutors were able to provide feedback to the course writers about the manuals of instruction.

Nevertheless, CCEUCC has proven that teacher preparation at a distance is effective. Distance education is feasible over a broad geographic area. It enables students to obtain the necessary education without disrupting the life and work of students. Distance education can provide an effective and efficient solution to the perennial shortage of trained teachers in both developed and developing worlds.

This study adds to the body of literature on the effectiveness and comprehensiveness of Provus' discrepancy evaluation model as a well tested systemic approach to the evaluation of academic programs.

\section{Recommendations}

The conclusion of this study has several implications for the CCEUCC specifically. Distance learning is a lonesome endeavor and the policy makers need to do whatever they can to ensure the provision of adequate learner support services in order to reduce the transactional distance between the learner, the tutor, and the administrative personnel. Since CCEUCC is providing a distance learning program in a developing country, it needs to seek to reach the optimum level of learner support in view of the limited availability of information and communication technology.

Successful program development cannot occur without evaluation (Sanders, 2000). CCEUCC therefore needs to add evaluation to the program, for without evaluation there is no feedback from the clients and other stakeholders. Without evaluation, the program cannot be aligned to the needs of the clients and stakeholders, and their satisfaction cannot be guaranteed.

Independent, self-directed, lifelong learning does not take place automatically (Brindley, 1995; Grow, 1991; Knowles et al., 2005; Wlodkwoski, 1999). Without independence and self-direction, distance learners cannot successfully achieve their goal of learning; therefore, providers of distance education need to develop a deliberate policy towards developing these attributes in their clients. CEUCC needs to include more learner-centered strategies into their teaching methodology. This will empower distance learners to own their learning and to assume more responsibility for their own success. 
More broadly, the conclusions of this study suggest that distance education can be very effective with sufficient investment in time and planning. The major areas of administration, course production, learner support, classroom supervision, choice of appropriate media, evaluation, and its end product of student achievement require adequate investment in resources and planning.

Educational systems facing a shortage of professionally trained teachers should strongly consider DE. It has been proven to be very effective if it is well planned and implemented. The literature shows that it has worked effectively in training teachers all over the world, developed and developing, including Africa, Brazil, Britain, China, Columbia, India, Indonesia, and the South Pacific. DE is suitable for both initial teacher education and continuing professional development. It has the added advantage of keeping teachers at post so they do not have to leave their jobs while receiving further professional development. DE has helped to bring education to the doorsteps of students who are unable to meet their educational needs in conventional institutions. 


\section{References}

Akyeampong, K. (2001). Teacher training in Ghana - does it count? Multi-Site Teacher Education Research (MUSTER) Country Report 1. East Sussex, UK: University of Sussex, Center for International Education.

Akyeampong, K., Furlong, D., \& Lewin, K. M. (2000). Costs and financing of teacher education in Ghana. Multi-Site Teacher Education Research Project (MUSTER) Discussion Paper 18. East Sussex, UK: University of Sussex, Center for International Education.

Aggor, R., Kinyanjui, P. E., Pecu, N. K., \& Yerbury, J. C. (1992). Survey on distance education in Ghana. Vancouver, British Columbia, Canada: The Commonwealth of Learning.

Alexander, J. W., Polyakova-Norwood, V., Johnston, L. W., Christensen, P., \& Loquist, R. S. (2003). Collaborative development and evaluation of an online nursing course. Distance Education, 24(1), 41-56.

Allen, M., Bourhis, J., Burrell, N., \& Mabry, E. (2002). Comparing student satisfaction with distance education to traditional classrooms in higher education: A meta-analysis. The American Journal of Distance Education, 16(2), 83-97.

Association for the Development of Education in Africa. (2004). Distance education and open learning in Sub-Saharan Africa: Criteria and conditions for quality and critical success factor - final report. ADEA and the Commonwealth of Learning. http://www.eric.ed.gov/ERICWebPortal/custom/portlets/recordDetails/detailmini.jsp?_nf $\mathrm{pb}=$ true\&_\&ERICExtSearch_SearchValue_0=ED503326\&ERICExtSearch_SearchType _0=no\&accno=ED503326

Brindley, J. E. (1995). Learners and learner services: The key to the future in distance education. In J. M. Roberts \& E. M. Keough (Eds.), Why the information highway: Lessons from open and distance learning (pp. 102-125). Toronto: Trifolium Books Inc. Retrieved January 20, 2007, from http://www.unioldenburg.de/zef/cde/support/readings/brind95c.pdf

Brindley, J. E. (2004). PREST handbook 6: Researching tutoring and learner support. The Commonwealth of Learning. Retrieved January 20, 2007, from http://www.col.org/SiteCollectionDocuments/B6.pdf

Brown, P. (2004, July). Learner support system: The experience of the Centre for Continuing Education, University of Cape Coast. Paper presented at the West African Teacher Training Consortium Workshop, Winneba, Ghana. 
Butcher, N. (2003). Technological infrastructure and use of ICT in education in Africa: An overview. Paris, France: ADEA/ Working Group on Distance Education and Open Learning (WGDEOL).

Calder, J. (1994). Programme evaluation and quality: A comprehensive guide to setting up an evaluation system. London: Kogan Page.

Center for Continuing Education University of Cape Coast (n. d.). Higher education for all: Programme design, diploma in basic education (DBE) and post-diploma in basic education (P-DBE).

Center for Evaluation and Research. (2001). Oakland Unified School District Urban Dreams Technology Challenge Grant project description and evaluation plan. Retrieved July 4, 2005, from http://californiaschools.net/ud/year2/dem2.htm

Darling-Hammond, L. (1998, February). Teacher learning that supports student learning. Educational Leadership, 55(5), 6-11.

DeJaeghere, J. G., Chapman, D. W., \& Mulkeen, A. (2004). Recruiting, retraining and retaining secondary school teachers and principals in sub-Saharan Africa. Washington, DC: World Bank and Academy for Educational Development.

DeJaeghere, J. G., Chapman, D. W., \& Mulkeen, A. (2006). Increasing the supply of secondary teachers in sub-Saharan Africa: A stakeholder assessment of policy options in six countries. Journal of Education Policy, 21(5), 515-533.

Feig, C. A. (1932). The effectiveness of correspondence study. Unpublished doctoral dissertation, The Pennsylvania State University.

Grow, G. O. (1991). Teaching learners to be self-directed. Adult Education Quarterly, 41, 125149.

Householder, D. L., \& Boser, R. A. (1991). Assessing the effectiveness of the change to technology teacher education. Journal of Technology Teacher Education 2(2). Retrieved May 25, 2005, from http://scholar.lib.vt.edu/ejournals/JTE/v2n2/html/house.html

Knowles, M. S., Holton III, F. E., \& Swanson, R. A. (2005). The adult learner: The definitive classic in adult education and human resource development $\left(6^{\text {th }}\right.$ ed.). New York: Elsevier Inc.

Larson, A. (1929). A study of the relative ability and achievement of class extension, correspondence, and resident students at the University of Kentucky. Unpublished master's thesis, University of Kentucky, Lexington, USA. 
Madaus, G. F., \& Kellaghan, T. (2000). Models, metaphors, and definitions in evaluation. In D. L. Dtufflebeam, G. F. Madaus, \& T. Kellaghan (Eds.), Evaluation models: Viewpoints on educational and human services evaluation ( $2^{\text {nd }}$ ed., pp. 19-32). Hingham, MA: Kluwer Academic Publishers.

Mark, M. M., Henry, G. T., \& Julnes, G. (2000). Evaluation: An integrated framework for understanding, guiding, and improving policies and programs. San Francisco: JosseyBass.

Ministry of Education. (2002). Ministry of Education report: Distance education workshop. Accra, Ghana: Government of Ghana.

Mrgan, C. A. (1999). Designing the design: A discrepancy evaluation of an educational technology program design and implementation in a community college. Unpublished doctoral dissertation, University of San Francisco, California.

Ossei-Anto, T. A. (2003). Distance and open learning at the University of Education, Winneba. In A. Gaskell \& A. Tait (Eds.), The $10^{\text {th }}$ Cambridge International Conference on Open and Distance Learning 2003. Collected conference papers. Cambridge, UK.

Perraton, H. (1993). (Ed.). Distance education for teacher training. London: Routledge.

Perraton, H. (2000). Open and distance learning in the developing world. New York: Rutledge.

Perraton, H., Creed, C., \& Robinson, B. (2002). Teacher education guideline: Using open and distance learning. Technology, curriculum, cost, evaluation. Paris, UNESCO, \& Cambridge: Division of Higher Education and Research, International Research Foundation for Open Learning.

Perraton, H., Robinson, B., \& Creed, C. (Eds.) (2007). International case studies of teacher education at a distance. Oldenburg: Bis-Verlag der Carl von Ossietsky Universität.

Peters, O. (1988). Distance teaching and industrial production: A comparative interpretation in outline. In D. Sewart, D. Keegan, \& B. Holmberg (Eds.), Distance education: International perspectives (pp. 95-113). New York: Routledge.

Provus, M. (1971). Discrepancy evaluation for educational program improvement and assessment. Berkeley, CA: McCutchan Publishing Corporation.

Robinson B., \& Latchem, C. R. (2002). Teacher education through open and distance learning. London: Routledge.

Rumble, G. (2002). The management of distance learning systems. Paris: UNESCO, International Institute for Educational Planning. 
Saint, W. (1999). Tertiary distance education and technology in sub-Saharan Africa. Washington, DC: Working Group on Higher Education, Association for the Development of Education in Africa (ADEA)/World Bank.

Schon, D. A. (1987). Educating the reflective practitioner. San Francisco: Jossey-Bass.

Shachar, M., \& Neumann, Y. (2003). Differences between traditional and distance education academic performances: A meta-analytic approach. The International Review of Research in Open and Distance Learning 4(2). Retrieved September 13, 2006, from http://www.irrodl.org/index.php/irrodl/article/view/153/234

Steinmetz, A. (2000). The discrepancy evaluation model. In D. L. Stufflebeam, G. F. Madaus, \& T. Kellaghan (Eds.), Evaluation models: Viewpoints on educational and human services evaluation ( $2^{\text {nd }}$ ed., pp. 127-143). Hingham, MA: Kluwer Academic Publishers.

Tait, A. (2000). Planning student support for open and distance Learning. Open Learning, 15(3), 287-299.

Tait, A. (2003). Reflections on student support in open and distance learning. International Review of Research in Open and Distance Learning, 4(1), 1-9. http://www.irrodl.org/index.php/irrodl/article/view/134/214

Thorpe, M. (1988). Evaluating open and distance learning. London: Longmans.

Thorpe, M. (2003). Rethinking learner support in distance education: Change and continuity in an international context. In A. Tait \& R. Mills. (Eds.), RoutledgeFarmer studies in distance education. London: RoutledgeFarmer.

Wlodkowski, R. J. (1999). Enhancing adult motivation to learn: A comprehensive guide for teaching all adults (Rev. ed.). San Francisco: Jossey-Bass.

Zhao, Y., Lei, J., Lai, B. Y. C., \& Tan, H. S., (August, 2005). What makes the difference? A practical analysis of research in the effectiveness of distance education. Teachers College Record, 107(8), 1836-1884. 


\section{Appendix A}

\section{Students Survey Instrument}

Please indicate your answer to the following items based on your experience with the Center for Continuing Education of the University of Cape Coast Distance Education program which you are currently involved. Circle the position that best represents your opinion.

\begin{tabular}{|c|c|c|c|c|c|}
\hline 1. & $\begin{array}{l}\text { The admission information was } \\
\text { easily understood. }\end{array}$ & $\begin{array}{l}\text { Strongly } \\
\text { Disagree }\end{array}$ & Disagree & Agree & $\begin{array}{l}\text { Strongly } \\
\text { Agree }\end{array}$ \\
\hline 2. & $\begin{array}{l}\text { The admission forms were designed } \\
\text { to be easy to complete. }\end{array}$ & $\begin{array}{l}\text { Strongly } \\
\text { Disagree }\end{array}$ & Disagree & Agree & $\begin{array}{l}\text { Strongly } \\
\text { Agree }\end{array}$ \\
\hline 3. & $\begin{array}{l}\text { The admission personnel were } \\
\text { helpful. }\end{array}$ & $\begin{array}{l}\text { Strongly } \\
\text { Disagree }\end{array}$ & Disagree & Agree & $\begin{array}{l}\text { Strongly } \\
\text { Agree }\end{array}$ \\
\hline 4. & $\begin{array}{l}\text { The Continuing Education catalog } \\
\text { presented information which was } \\
\text { easy to understand. } \\
\end{array}$ & $\begin{array}{l}\text { Strongly } \\
\text { Disagree }\end{array}$ & Disagree & Agree & $\begin{array}{l}\text { Strongly } \\
\text { Agree }\end{array}$ \\
\hline 5. & $\begin{array}{l}\text { The orientation seminar was } \\
\text { beneficial. }\end{array}$ & $\begin{array}{l}\text { Strongly } \\
\text { Disagree }\end{array}$ & Disagree & Agree & $\begin{array}{l}\text { Strongly } \\
\text { Agree }\end{array}$ \\
\hline 6. & $\begin{array}{l}\text { I received course materials in time } \\
\text { at the beginning of the semester }\end{array}$ & $\begin{array}{l}\text { Strongly } \\
\text { Disagree }\end{array}$ & Disagree & Agree & $\begin{array}{l}\text { Strongly } \\
\text { Agree }\end{array}$ \\
\hline 7. & $\begin{array}{l}\text { The course manuals contained } \\
\text { course objectives so I had a general } \\
\text { idea of the structure and direction at } \\
\text { the beginning of the course }\end{array}$ & $\begin{array}{l}\text { Strongly } \\
\text { Disagree }\end{array}$ & Disagree & Agree & $\begin{array}{l}\text { Strongly } \\
\text { Agree }\end{array}$ \\
\hline 8. & $\begin{array}{l}\text { The manuals were easy to read and } \\
\text { understand }\end{array}$ & $\begin{array}{l}\text { Strongly } \\
\text { Disagree }\end{array}$ & Disagree & Agree & $\begin{array}{l}\text { Strongly } \\
\text { Agree }\end{array}$ \\
\hline 9. & $\begin{array}{l}\text { The graphics in the manuals were } \\
\text { clear and self-explanatory }\end{array}$ & $\begin{array}{l}\text { Strongly } \\
\text { Disagree }\end{array}$ & Disagree & Agree & $\begin{array}{l}\text { Strongly } \\
\text { Agree }\end{array}$ \\
\hline 10. & $\begin{array}{l}\text { The examples in the manuals were } \\
\text { realistic to my classroom } \\
\text { experience as a teacher }\end{array}$ & $\begin{array}{l}\text { Strongly } \\
\text { Disagree }\end{array}$ & Disagree & Agree & $\begin{array}{l}\text { Strongly } \\
\text { Agree }\end{array}$ \\
\hline 11. & $\begin{array}{l}\text { The course tutor returned graded } \\
\text { assignments to me in a reasonable } \\
\text { length of time. }\end{array}$ & $\begin{array}{l}\text { Strongly } \\
\text { Disagree }\end{array}$ & Disagree & Agree & $\begin{array}{l}\text { Strongly } \\
\text { Agree }\end{array}$ \\
\hline 12. & $\begin{array}{l}\text { The course tutor provided me with } \\
\text { positive feedback during the course }\end{array}$ & $\begin{array}{l}\text { Strongly } \\
\text { Disagree }\end{array}$ & Disagree & Agree & $\begin{array}{l}\text { Strongly } \\
\text { Agree }\end{array}$ \\
\hline 13. & $\begin{array}{l}\text { I felt comfortable communicating } \\
\text { with the course tutor concerning my } \\
\text { studies. }\end{array}$ & $\begin{array}{l}\text { Strongly } \\
\text { Disagree }\end{array}$ & Disagree & Agree & $\begin{array}{l}\text { Strongly } \\
\text { Agree }\end{array}$ \\
\hline 14. & $\begin{array}{l}\text { I felt comfortable communicating } \\
\text { with course tutor concerning my } \\
\text { personal problems. }\end{array}$ & $\begin{array}{l}\text { Strongly } \\
\text { Disagree }\end{array}$ & Disagree & Agree & $\begin{array}{l}\text { Strongly } \\
\text { Agree }\end{array}$ \\
\hline 15. & $\begin{array}{l}\text { During monthly face to face } \\
\text { tutorials course tutors related to me } \\
\text { more as facilitators of self-directed } \\
\text { learners rather than as transmitters } \\
\text { of information. }\end{array}$ & $\begin{array}{l}\text { Strongly } \\
\text { Disagree }\end{array}$ & Disagree & Agree & $\begin{array}{l}\text { Strongly } \\
\text { Agree }\end{array}$ \\
\hline 16. & $\begin{array}{l}\text { The study center coordinator } \\
\text { answered all my questions } \\
\text { adequately. }\end{array}$ & $\begin{array}{l}\text { Strongly } \\
\text { Disagree }\end{array}$ & Disagree & Agree & $\begin{array}{l}\text { Strongly } \\
\text { Agree }\end{array}$ \\
\hline
\end{tabular}




\section{Students Survey Instrument (continued.)}

\begin{tabular}{|c|c|c|c|c|c|}
\hline 17. & $\begin{array}{l}\quad \text { I regard comments on my } \\
\text { returned assignments as a dialogue } \\
\text { rather than a directive from the course } \\
\text { tutor }\end{array}$ & $\begin{array}{l}\text { Strongly } \\
\text { Disagree }\end{array}$ & Disagree & Agree & $\begin{array}{l}\text { Strongly } \\
\text { Agree }\end{array}$ \\
\hline 18. & $\begin{array}{l}\text { Tutorials at the study center are } \\
\text { student-centered instead of teacher- } \\
\text { centered. }\end{array}$ & $\begin{array}{l}\text { Strongly } \\
\text { Disagree }\end{array}$ & Disagree & Agree & $\begin{array}{l}\text { Strongly } \\
\text { Agree }\end{array}$ \\
\hline 19. & $\begin{array}{l}\text { I would have liked to have had } \\
\text { more personal contact with the } \\
\text { instructor. }\end{array}$ & $\begin{array}{l}\text { Strongly } \\
\text { Disagree }\end{array}$ & Disagree & Agree & $\begin{array}{l}\text { Strongly } \\
\text { Agree }\end{array}$ \\
\hline 20. & $\begin{array}{l}\text { The course manuals encourage } \\
\text { collaborative work among us } \\
\text { students. }\end{array}$ & $\begin{array}{l}\text { Strongly } \\
\text { Disagree }\end{array}$ & Disagree & Agree & $\begin{array}{l}\text { Strongly } \\
\text { Agree }\end{array}$ \\
\hline 21. & $\begin{array}{l}\quad \text { My classroom supervisor } \\
\text { appointed by the University visited } \\
\text { my class room at least twice each } \\
\text { semester. }\end{array}$ & $\begin{array}{l}\text { Strongly } \\
\text { Disagree }\end{array}$ & Disagree & Agree & $\begin{array}{l}\text { Strongly } \\
\text { Agree }\end{array}$ \\
\hline 22. & $\begin{array}{l}\text { My classroom supervisor was a } \\
\text { source of information at every visit. }\end{array}$ & $\begin{array}{l}\text { Strongly } \\
\text { Disagree }\end{array}$ & Disagree & Agree & $\begin{array}{l}\text { Strongly } \\
\text { Agree }\end{array}$ \\
\hline 23. & $\begin{array}{l}\text { The supervisor's visit always } \\
\text { made me nervous. }\end{array}$ & $\begin{array}{l}\text { Strongly } \\
\text { Disagree }\end{array}$ & Disagree & Agree & $\begin{array}{l}\text { Strongly } \\
\text { Agree }\end{array}$ \\
\hline 24. & $\begin{array}{l}\text { The supervisor's visit to my } \\
\text { classroom helped me to connect my } \\
\text { course work to my classroom } \\
\text { teaching practice. }\end{array}$ & $\begin{array}{l}\text { Strongly } \\
\text { Disagree }\end{array}$ & Disagree & Agree & $\begin{array}{l}\text { Strongly } \\
\text { Agree }\end{array}$ \\
\hline 25. & $\begin{array}{l}\text { I had access to a computer at the } \\
\text { study center with internet } \\
\text { connectivity to do my research and } \\
\text { send emails to my course tutor. }\end{array}$ & $\begin{array}{l}\text { Strongly } \\
\text { Disagree }\end{array}$ & Disagree & Agree & $\begin{array}{l}\text { Strongly } \\
\text { Agree }\end{array}$ \\
\hline 26. & $\begin{array}{l}\text { Test questions often consisted of } \\
\text { a test of critical thinking skills }\end{array}$ & $\begin{array}{l}\text { Strongly } \\
\text { Disagree }\end{array}$ & Disagree & Agree & $\begin{array}{l}\text { Strongly } \\
\text { Agree }\end{array}$ \\
\hline 27. & $\begin{array}{l}\text { Test questions often consisted of } \\
\text { only a test of memorization abilities. }\end{array}$ & $\begin{array}{l}\text { Strongly } \\
\text { Disagree }\end{array}$ & Disagree & Agree & $\begin{array}{l}\text { Strongly } \\
\text { Agree }\end{array}$ \\
\hline 28. & $\begin{array}{l}\text { Course assignments often } \\
\text { required research writing. }\end{array}$ & $\begin{array}{l}\text { Strongly } \\
\text { Disagree }\end{array}$ & Disagree & Agree & $\begin{array}{l}\text { Strongly } \\
\text { Agree }\end{array}$ \\
\hline 29. & $\begin{array}{l}\text { I prefer correspondence study to } \\
\text { classroom instruction. }\end{array}$ & $\begin{array}{l}\text { Strongly } \\
\text { Disagree }\end{array}$ & Disagree & Agree & $\begin{array}{l}\text { Strongly } \\
\text { Agree }\end{array}$ \\
\hline 30. & $\begin{array}{l}\text { I would recommend UCC } \\
\text { correspondence course to my friends, } \\
\text { relatives, etc. who are in the teaching } \\
\text { profession. }\end{array}$ & $\begin{array}{l}\text { Strongly } \\
\text { Disagree }\end{array}$ & Disagree & Agree & $\begin{array}{l}\text { Strongly } \\
\text { Agree }\end{array}$ \\
\hline 31. & $\begin{array}{l}\text { I found the educational } \\
\text { experience personally rewarding. }\end{array}$ & $\begin{array}{l}\text { Strongly } \\
\text { Disagree }\end{array}$ & Disagree & Agree & $\begin{array}{l}\text { Strongly } \\
\text { Agree }\end{array}$ \\
\hline 32. & $\begin{array}{l}\text { This course contributed to my } \\
\text { academic development. }\end{array}$ & $\begin{array}{l}\text { Strongly } \\
\text { Disagree }\end{array}$ & Disagree & Agree & $\begin{array}{l}\text { Strongly } \\
\text { Agree }\end{array}$ \\
\hline 33. & $\begin{array}{l}\text { This course contributed to my } \\
\text { professional development. }\end{array}$ & $\begin{array}{l}\text { Strongly } \\
\text { Disagree }\end{array}$ & Disagree & Agree & $\begin{array}{l}\text { Strongly } \\
\text { Agree }\end{array}$ \\
\hline 34. & $\begin{array}{l}\text { The advisors motivated me to } \\
\text { complete the course. }\end{array}$ & $\begin{array}{l}\text { Strongly } \\
\text { Disagree }\end{array}$ & Disagree & Agree & $\begin{array}{l}\text { Strongly } \\
\text { Agree }\end{array}$ \\
\hline
\end{tabular}


35. Is this your first correspondence program?

(a) yes.

(b) no.

If no specify which correspondence course you have involved in before in space below

\section{Student s Survey Instrument Continued.}

36. How many years were you teaching before enrolling in the Center for Continuing Education program?

37. What was your initial qualification before enrolling in this correspondence program?

38. How many hours per week do you devote to the course?

39. Feel free to write below any other information you would like to add the enhance my understanding of your feeling towards the program 


\section{Appendix B}

\section{Faculty/Administrators' Survey Instrument}

Kindly indicate your answer $t$ the following items based on your experience as a faculty member or administrator. Circle the position that best represents your opinion.

\begin{tabular}{|c|c|c|c|c|c|c|}
\hline 1. & $\begin{array}{l}\text { I believe the study centers are } \\
\text { adequately equipped with furniture } \\
\text { for learning to take place there }\end{array}$ & $\begin{array}{l}\text { Strongly } \\
\text { Disagree }\end{array}$ & Disagree & $\begin{array}{c}\text { No } \\
\text { Opinion }\end{array}$ & Agree & $\begin{array}{l}\text { Strongly } \\
\text { Agree }\end{array}$ \\
\hline 2. & $\begin{array}{l}\text { The study center I am familiar with } \\
\text { has the necessary communication } \\
\text { equipment i.e. telephone and } \\
\text { computers with internet } \\
\text { connectivity }\end{array}$ & $\begin{array}{l}\text { Strongly } \\
\text { Disagree }\end{array}$ & Disagree & $\begin{array}{c}\text { No } \\
\text { Opinion }\end{array}$ & Agree & $\begin{array}{l}\text { Strongly } \\
\text { Agree }\end{array}$ \\
\hline 3. & $\begin{array}{l}\text { Learner information is collected, } \\
\text { stored and used on a consistent } \\
\text { basis }\end{array}$ & $\begin{array}{l}\text { Strongly } \\
\text { Disagree }\end{array}$ & Disagree & $\begin{array}{c}\text { No } \\
\text { Opinion }\end{array}$ & Agree & $\begin{array}{l}\text { Strongly } \\
\text { Agree }\end{array}$ \\
\hline 4. & $\begin{array}{l}\text { Data collected about the program } \\
\text { are analyzed and used for the } \\
\text { improvement of the program }\end{array}$ & $\begin{array}{l}\text { Strongly } \\
\text { Disagree }\end{array}$ & Disagree & $\begin{array}{c}\text { No } \\
\text { Opinion }\end{array}$ & Agree & $\begin{array}{l}\text { Strongly } \\
\text { Agree }\end{array}$ \\
\hline 5. & $\begin{array}{l}\text { The turnaround time of students' } \\
\text { assignment is reasonable }\end{array}$ & $\begin{array}{l}\text { Strongly } \\
\text { Disagree }\end{array}$ & Disagree & $\begin{array}{c}\text { No } \\
\text { Opinion } \\
\end{array}$ & Agree & $\begin{array}{l}\text { Strongly } \\
\text { Agree }\end{array}$ \\
\hline 6. & $\begin{array}{l}\text { Learning and assessment methods } \\
\text { are appropriate to the purpose and } \\
\text { outcomes of the program }\end{array}$ & $\begin{array}{l}\text { Strongly } \\
\text { Disagree }\end{array}$ & Disagree & $\begin{array}{c}\text { No } \\
\text { Opinion }\end{array}$ & Agree & $\begin{array}{l}\text { Strongly } \\
\text { Agree }\end{array}$ \\
\hline 7. & $\begin{array}{l}\text { The courses are coherently designed } \\
\text { and packaged }\end{array}$ & $\begin{array}{l}\text { Strongly } \\
\text { Disagree }\end{array}$ & Disagree & $\begin{array}{c}\text { No } \\
\text { Opinion }\end{array}$ & Agree & $\begin{array}{l}\text { Strongly } \\
\text { Agree }\end{array}$ \\
\hline 8. & $\begin{array}{l}\text { The tutorials are student-centered } \\
\text { instead of teacher-centered }\end{array}$ & $\begin{array}{l}\text { Strongly } \\
\text { Disagree }\end{array}$ & Disagree & $\begin{array}{c}\text { No } \\
\text { Opinion } \\
\end{array}$ & Agree & $\begin{array}{l}\text { Strongly } \\
\text { Agree }\end{array}$ \\
\hline 9. & $\begin{array}{l}\text { The content of the courses and } \\
\text { practice of tutors encourage } \\
\text { collaborative learning }\end{array}$ & $\begin{array}{l}\text { Strongly } \\
\text { Disagree }\end{array}$ & Disagree & $\begin{array}{c}\text { No } \\
\text { Opinion }\end{array}$ & Agree & $\begin{array}{l}\text { Strongly } \\
\text { Agree }\end{array}$ \\
\hline 10. & $\begin{array}{l}\text { The course materials are accessibly } \\
\text { presented }\end{array}$ & $\begin{array}{l}\text { Strongly } \\
\text { Disagree }\end{array}$ & Disagree & $\begin{array}{c}\text { No } \\
\text { Opinion }\end{array}$ & Agree & $\begin{array}{l}\text { Strongly } \\
\text { Agree }\end{array}$ \\
\hline 11. & $\begin{array}{l}\text { The course materials present } \\
\text { information in a coherent way that } \\
\text { engages the learners }\end{array}$ & $\begin{array}{l}\text { Strongly } \\
\text { Disagree }\end{array}$ & Disagree & $\begin{array}{c}\text { No } \\
\text { Opinion }\end{array}$ & Agree & $\begin{array}{l}\text { Strongly } \\
\text { Agree }\end{array}$ \\
\hline 12. & $\begin{array}{l}\text { There is an identified process of } \\
\text { development and evaluation of } \\
\text { course materials }\end{array}$ & $\begin{array}{l}\text { Strongly } \\
\text { Disagree }\end{array}$ & Disagree & $\begin{array}{c}\text { No } \\
\text { Opinion }\end{array}$ & Agree & $\begin{array}{l}\text { Strongly } \\
\text { Agree }\end{array}$ \\
\hline 13. & $\begin{array}{l}\text { The course materials encourage } \\
\text { learners to exercise their inquiry } \\
\text { abilities through constructivist } \\
\text { approaches }\end{array}$ & $\begin{array}{l}\text { Strongly } \\
\text { Disagree }\end{array}$ & Disagree & $\begin{array}{c}\text { No } \\
\text { Opinion }\end{array}$ & Agree & $\begin{array}{l}\text { Strongly } \\
\text { Agree }\end{array}$ \\
\hline 14. & $\begin{array}{l}\text { The course materials encourage } \\
\text { reflection and connection between } \\
\text { theory and practice }\end{array}$ & $\begin{array}{l}\text { Strongly } \\
\text { Disagree }\end{array}$ & Disagree & $\begin{array}{c}\text { No } \\
\text { Opinion }\end{array}$ & Agree & $\begin{array}{l}\text { Strongly } \\
\text { Agree }\end{array}$ \\
\hline 15. & $\begin{array}{l}\text { The course materials take into } \\
\text { consideration different learning } \\
\text { styles of students }\end{array}$ & $\begin{array}{l}\text { Strongly } \\
\text { Disagree }\end{array}$ & Disagree & $\begin{array}{c}\text { No } \\
\text { Opinion }\end{array}$ & Agree & $\begin{array}{l}\text { Strongly } \\
\text { Agree }\end{array}$ \\
\hline 16. & $\begin{array}{l}\text { Assessment is done in a way that } \\
\text { minimizes stress for learners by } \\
\text { making the process transparent, }\end{array}$ & $\begin{array}{l}\text { Strongly } \\
\text { Disagree }\end{array}$ & Disagree & $\begin{array}{c}\text { No } \\
\text { Opinion }\end{array}$ & Agree & $\begin{array}{l}\text { Strongly } \\
\text { Agree }\end{array}$ \\
\hline
\end{tabular}




\begin{tabular}{|c|c|c|c|c|c|c|}
\hline & $\begin{array}{l}\text { supportive and affirming while not } \\
\text { compromising on the standards } \\
\text { required }\end{array}$ & & & & & \\
\hline 17. & $\begin{array}{l}\text { Learner support is an integral part of } \\
\text { the design of the program }\end{array}$ & $\begin{array}{l}\text { Strongly } \\
\text { Disagree }\end{array}$ & Disagree & $\begin{array}{c}\text { No } \\
\text { Opinion }\end{array}$ & Agree & $\begin{array}{l}\text { Strongly } \\
\text { Agree }\end{array}$ \\
\hline 18. & $\begin{array}{l}\text { There is time block earmarked for } \\
\text { one-on-one interaction with tutor for } \\
\text { those who need it. }\end{array}$ & $\begin{array}{l}\text { Strongly } \\
\text { Disagree }\end{array}$ & pisagree & $\begin{array}{c}\text { No } \\
\text { Opinion }\end{array}$ & Agree & $\begin{array}{l}\text { Strongly } \\
\text { Agree }\end{array}$ \\
\hline 19. & $\begin{array}{l}\text { I feel adequately prepared to offer } \\
\text { student support by means of } \\
\text { counseling }\end{array}$ & $\begin{array}{l}\text { Strongly } \\
\text { Disagree }\end{array}$ & pisagree & $\begin{array}{c}\text { No } \\
\text { Opinion }\end{array}$ & Agree & $\begin{array}{l}\text { Strongly } \\
\text { Agree }\end{array}$ \\
\hline 20. & $\begin{array}{l}\text { Course tutors/supervisors/study } \\
\text { center coordinators often do } \\
\text { counseling to students }\end{array}$ & $\begin{array}{l}\text { Strongly } \\
\text { Disagree }\end{array}$ & pisagree & $\begin{array}{c}\text { No } \\
\text { Opinion }\end{array}$ & Agree & $\begin{array}{l}\text { Strongly } \\
\text { Agree }\end{array}$ \\
\hline 21. & $\begin{array}{l}\text { Course tutors use different modes } \\
\text { of instruction, (e.g. lectures, } \\
\text { discussion, role-playing, overhead } \\
\text { projectors, etc.) during face to face } \\
\text { seminars. }\end{array}$ & $\begin{array}{l}\text { Strongly } \\
\text { Disagree }\end{array}$ & Disagree & $\begin{array}{c}\text { No } \\
\text { Opinion }\end{array}$ & Agree & $\begin{array}{l}\text { Strongly } \\
\text { Agree }\end{array}$ \\
\hline 22. & $\begin{array}{l}\text { The program integrates } \\
\text { encouragement of peer support } \\
\text { structures }\end{array}$ & $\begin{array}{l}\text { Strongly } \\
\text { Disagree }\end{array}$ & Disagree & $\begin{array}{c}\text { No } \\
\text { Opinion }\end{array}$ & Agree & $\begin{array}{l}\text { Strongly } \\
\text { Agree }\end{array}$ \\
\hline 23. & $\begin{array}{l}\text { Course tutors act as facilitators of } \\
\text { self-directed learning instead of } \\
\text { didactic transmitters of information }\end{array}$ & $\begin{array}{l}\text { Strongly } \\
\text { Disagree }\end{array}$ & pisagree & $\begin{array}{c}\text { No } \\
\text { Opinion }\end{array}$ & Agree & $\begin{array}{l}\text { Strongly } \\
\text { Agree }\end{array}$ \\
\hline 24. & $\begin{array}{l}\text { The program integrate staff } \\
\text { development in such a way that all } \\
\text { staff are continually learning as they } \\
\text { contribute to the functioning of the } \\
\text { program }\end{array}$ & $\begin{array}{l}\text { Strongly } \\
\text { Disagree }\end{array}$ & pisagree & $\begin{array}{c}\text { No } \\
\text { Opinion }\end{array}$ & Agree & $\begin{array}{l}\text { Strongly } \\
\text { Agree }\end{array}$ \\
\hline 25. & $\begin{array}{l}\text { Course writers actually visit study } \\
\text { centers and try to get feedback from } \\
\text { both students and tutors on how their } \\
\text { manuals are used }\end{array}$ & $\begin{array}{l}\text { Strongly } \\
\text { Disagree }\end{array}$ & Disagree & $\begin{array}{c}\text { No } \\
\text { Opinion }\end{array}$ & Agree & $\begin{array}{l}\text { Strongly } \\
\text { Agree }\end{array}$ \\
\hline 26. & $\begin{array}{l}\text { Efficient administrative systems } \\
\text { support the activities of the program }\end{array}$ & $\begin{array}{l}\text { Strongly } \\
\text { Disagree }\end{array}$ & Disagree & $\begin{array}{c}\text { No } \\
\text { Opinion } \\
\end{array}$ & Agree & $\begin{array}{l}\text { Strongly } \\
\text { Agree }\end{array}$ \\
\hline 27. & $\begin{array}{l}\text { Tutors encourage student-teachers } \\
\text { to regard tutors' comments on marked } \\
\text { scripts as a dialogue and not a } \\
\text { directive }\end{array}$ & $\begin{array}{l}\text { Strongly } \\
\text { Disagree }\end{array}$ & pisagree & $\begin{array}{c}\text { No } \\
\text { Opinion }\end{array}$ & Agree & $\begin{array}{l}\text { Strongly } \\
\text { Agree }\end{array}$ \\
\hline 28. & $\begin{array}{l}\text { There is an integrated framework } \\
\text { at a policy and practice level that } \\
\text { informs a clear cycle of planning, } \\
\text { implementation, monitoring, reflection } \\
\text { and action to ensure that learners' and } \\
\text { staff needs as well as the needs of } \\
\text { other clients are met }\end{array}$ & $\begin{array}{l}\text { Strongly } \\
\text { Disagree }\end{array}$ & pisagree & $\begin{array}{c}\text { No } \\
\text { Opinion }\end{array}$ & Agree & $\begin{array}{l}\text { Strongly } \\
\text { Agree }\end{array}$ \\
\hline 29. & $\begin{array}{l}\text { Information about scope, } \\
\text { requirements and benefits of the } \\
\text { program is disseminated in such a way } \\
\text { that every potential learner receives it. }\end{array}$ & $\begin{array}{l}\text { Strongly } \\
\text { Disagree }\end{array}$ & pisagree & $\begin{array}{c}\text { No } \\
\text { Opinion }\end{array}$ & Agree & $\begin{array}{l}\text { Strongly } \\
\text { Agree }\end{array}$ \\
\hline 30. & $\begin{array}{l}\text { Supervisors often visit student- } \\
\text { teacher's classroom }\end{array}$ & $\begin{array}{l}\text { Strongly } \\
\text { Disagree }\end{array}$ & Disagree & $\begin{array}{l}\text { No } \\
\text { Opinion }\end{array}$ & Agree & $\begin{array}{l}\text { Strongly } \\
\text { Agree }\end{array}$ \\
\hline 31. & $\begin{array}{l}\text { Supervisors' bi-weekly reports } \\
\text { are analyzed and used to improve }\end{array}$ & $\begin{array}{l}\text { Strongly } \\
\text { Disagree }\end{array}$ & Disagree & $\begin{array}{l}\text { No } \\
\text { Opinion }\end{array}$ & Agree & $\begin{array}{l}\text { Strongly } \\
\text { Agree }\end{array}$ \\
\hline
\end{tabular}




\begin{tabular}{|c|c|c|c|c|c|c|}
\hline & program & & & & & \\
\hline 32. & $\begin{array}{l}\text { There is a mechanism in place } \\
\text { to ensure that supervisors visit } \\
\text { student-teachers' classroom }\end{array}$ & $\begin{array}{l}\text { Strongly } \\
\text { Disagree }\end{array}$ & pisagree & $\begin{array}{l}\text { No } \\
\text { Opinion }\end{array}$ & Agree & $\begin{array}{l}\text { Strongly } \\
\text { Agree }\end{array}$ \\
\hline 33. & $\begin{array}{l}\text { In my estimation, student- } \\
\text { teachers are utilizing what they are } \\
\text { learning through this program in } \\
\text { their classroom }\end{array}$ & $\begin{array}{l}\text { Strongly } \\
\text { Disagree }\end{array}$ & Disagree & $\begin{array}{l}\text { No } \\
\text { Opinion }\end{array}$ & Agree & $\begin{array}{l}\text { Strongly } \\
\text { Agree }\end{array}$ \\
\hline 34. & $\begin{array}{l}\text { In my estimation, the Distance } \\
\text { Teacher Education program of } \\
\text { CCEUCC has had a positive } \\
\text { impact on teacher education in the } \\
\text { country }\end{array}$ & $\begin{array}{l}\text { Strongly } \\
\text { Disagree }\end{array}$ & Disagree & $\begin{array}{l}\text { No } \\
\text { Opinion }\end{array}$ & Agree & $\begin{array}{l}\text { Strongly } \\
\text { Agree }\end{array}$ \\
\hline
\end{tabular}

35. Kindly circle your position below:
(a) Course Writer,
(b) Course Tutor,
(c) Classroom Supervisor
(d) Study Center Coordinator

36. How far away from the study center/ student-teachers' classroom are you

37. What means of transportation do you normally use?

38. Feel free to write below any other information you would like to add the enhance my understanding of your feeling towards the program

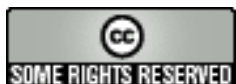

